\title{
РЕГИОНАЛЬНЫЕ ПОЛИТИЧЕСКИЕ ПРОЦЕССЫ
}

УДК $327.7 ; 327.56$

\author{
Н. Н. Гудалов
}

\section{РАЗВИТИЕ И ОСОБЕННОСТИ ПОЗИЦИИ ЕВРОПЕЙСКОГО СОЮЗА ПО ОСНОВНЫМ ПОЛИТИЧЕСКИМ АСПЕКТАМ РАЗРЕШЕНИЯ ПАЛЕСТИНО-ИЗРАИЛЬСКОГО КОНФЛИКТА}

За годы развития европейской интеграции была выработана - сначала в рамках Европейского политического сотрудничества, а затем - Общей внешней политики и политики безопасности - относительно единая позиция государств - членов Европейских сообществ и Европейского союза касательно ключевых политических аспектов разрешения палестиноизраильского конфликта. ЕС стремится гарантировать национальное самоопределение израильтян и палестинцев и соблюдение международного гуманитарного права и прав человека. Однако позиция ЕС страдает от недостатка внутреннего единства и содержательной противоречивости. Библиогр. 78 назв.

Ключевые слова: Общая внешняя политика и политика безопасности Европейского союза, палестино-израильский конфликт, разрешение международных конфликтов, третья сторона в международных конфликтах.

\section{N.N. Gudalov \\ THE DEVELOPMENT AND CHARACTERISTICS OF THE EUROPEAN UNION'S POSITION ON THE PRINCIPAL POLITICAL ASPECTS OF THE RESOLUTION OF THE ISRAELI-PALESTINIAN CONFLICT}

Over the years of the evolution of European integration, a common position of the European Communities' member states and of the European Union has been elaborated - at first within the framework of the European Political Cooperation, then of the Common Foreign and Security Policy — regarding the key political aspects of the resolution of the Israeli-Palestinian conflict. The EU seeks to guarantee the national self-determination of the Israelis and the Palestinians and the compliance with the international humanitarian law and human rights. Yet, the EU's position suffers from a lack of internal coherence within the EU and from substantial inconsistencies. Refs 78.

Keywords: Common Foreign and Security Policy of the European Union, Israeli-Palestinian conflict, international conflict resolution, third party in international conflicts.

\section{Введение}

Относительно единая позиция государств - членов Европейского союза (EC) в отношении ключевых параметров разрешения палестино-израильского конфликта начала складываться задолго до создания самого ЕС и официального

Гудалов Николай Николаевич - кандидат политических наук, старший преподаватель, СанктПетербургский государственный университет, Российская Федерация, 199034, Санкт-Петербург, Университетская наб., 7-9; n.gudalov@spbu.ru

Gudalov Nikolay N. - PhD, Senior Lecturer, Saint Petersburg State University, 7-9, Universitetskaya nab., St. Petersburg, 199034, Russian Federation; n.gudalov@spbu.ru

() Санкт-Петербургский государственный университет, 201 
старта палестино-израильского мирного процесса в Осло в 1993 г. В некоторой степени сам конфликт можно рассматривать как катализатор запуска Европейского политического сотрудничества (ЕПС)ํㅜ в 1970 г. Так, в 1967 г. члены Европейских сообществ не смогли выработать общей реакции на Шестидневную войну, и канцлер ФРГ Курт Кизингер впоследствии говорил, что ему было «стыдно» [1, p. 116]. Конфликт стал предметом обсуждения в самом начале функционирования как Европейского политического сотрудничества, так и сменившей его в 1993 г. Общей внешней политики и политики безопасности (ОВПБ) [1, р.116; 2, р.293-294]. Уже к 1973 г. под эгидой ЕПС была создана рабочая группа по Ближнему Востоку наряду с рабочими группами по Средиземноморью и Азии [3]. Важность мира на Ближнем Востоке отражалась в многочисленных документах ЕС (и государств - членов Европейских сообществ), в том числе стратегического значения. В период ЕПС к таковым относились, в частности, Декларация о европейской идентичности 1973 г. [4]; на современном этапе (после начала Процесса Осло) - Общая стратегия ЕС по Средиземноморскому региону (одна из трех общих стратегий, принятых ЕС за все время) [5], Европейская стратегия безопасности 2003 г. [6] и Глобальная стратегия EC 2016 г. [7]. Элементы позиции ЕС относительно конфликта не раз определялись в заключениях Европейского совета - документах, исходящих от глав государств и правительств стран-членов. Таким образом, разрешение конфликта рассматривалось ЕС как один из важнейших международных приоритетов [8, p. 14]. В свою очередь, поддержанные Европейскими сообществами и ЕС ориентиры, которые первоначально были неприемлемы ни для Израиля, ни для США, со временем легли в основу планов по решению конфликта, которые сейчас разделяет бо́льшая часть международного сообщества.

В связи с этим достаточно актуальной представляется цель настоящей статьи - проследить историю становления и выявить особенности позиции ЕС по основным политическим аспектам разрешения палестино-израильского конфликта. При этом все остальные проблемы участия ЕС в процессе разрешения конфликта - например, его экономическая роль, детали практической реализации позиции или вклад отдельных государств-членов - требуют отдельного анализа и в статье рассматриваться не будут.

В мировой науке затронутым вопросом занимаются Д.Аллен, М.Смит [9], А.Амбос, И.Фон Бер [2], Р.Гинзберг [10], Р.Даннройтер [11], П. Мюллер [12], Ш.Пардо, Дж.Питерс [13], Г.Сакер [14], Н. Точчи [8]. Среди работ российских ученых, исследующих институты и внешнюю деятельность ЕС, можно отметить труды Н.Заславской [15], В. Морозова [16], Т. Романовой [17]. Особое внимание в отечественной научной литературе уделяется политике ЕС в отношении России и постсоветского пространства - данную тему разрабатывают такие исследователи, как Ю.Мишальченко, А. Изотов [18], С. Ткаченко [19], К. Худолей [20]. Однако что касается внешней деятельности Евросоюза в целом (а не отдельных государствчленов) в отношении палестино-израильского конфликта, то в российской науке

${ }^{1}$ Европейское политическое сотрудничество де-юре развивалось в межгосударственном формате за рамками интеграции в Европейских сообществах. Поэтому всякий раз, когда в статье для краткости говорится о «позиции (политике) Сообществ» по внешнеполитическим вопросам в период ЕПС, имеется в виду общая позиция (политика) их государств-членов, выработанная вне процедур «коммунитарной» интеграции. 
имеются лишь немногочисленные работы по отдельным аспектам данной темы. Они принадлежат О.Зыковой [21], А. Колобову [22], А. Крылову [23], Д. Кутрашеву [24]. При этом позиции других внешних акторов в палестино-израильском (и во всем арабо-израильском) конфликте - в том числе Российской Федерации, США, $\mathrm{OOH}$ - освещаются российскими исследователями достаточно подробно. Среди работ необходимо отметить исследования Д. Голубева, посвященные посреднической роли США в арабо-израильском конфликте [25]. Таким образом, в российской науке почти не исследованы долгая история становления, многоаспектность и противоречивость позиции ЕС по ключевым политическим проблемам палестино-израильского конфликта. Данная статья призвана частично заполнить этот пробел.

\section{Позиция ЕС в отношении национального самоопределения израильтян и палестинцев}

Позиция ЕС в отношении конфликта опирается на два взаимосвязанных ориентира. Первый состоит в обеспечении национального самоопределения двух народов - израильского и палестинского. Второй касается защиты прав человека и соблюдения международного гуманитарного права (МГП) [8, p. 12-14]. Переплетение этих двух составляющих отразилось в важнейшем вопросе о признании ЕС тех акторов, которые претендуют на то, чтобы представлять палестинцев (Организации освобождения Палестины - ООП, Движения исламского сопротивления ХАMAC). На этот вопрос нужно обратить отдельное внимание.

Формирование первой составляющей позиции ЕС произошло следующим образом. Все шесть государств - основателей Сообществ признали резолюцию 242 Совета Безопасности (СБ) ООН 1967 г. в год ее принятия [10, p. 112], что отразило их безусловную поддержку «суверенитета, территориальной целостности и политической независимости... и... права жить в мире в безопасных и признанных границах» [26] всех ближневосточных государств, включая Израиль. Впоследствии Сообщества и ЕС никогда не ставили данные права Израиля и других государств под вопрос.

В отношении самоопределения палестинцев их позиция прошла длительное развитие. Еще до институционализации ЕПС конфиденциальный рабочий документ Сообществ «рекомендовал отход Израиля к границам до войны 1967 г., возвращение беженцев или компенсации тем, кто не вернется, и интернационализацию Иерусалима» [10, р.112]. Эта позиция легла в основу так называемого Документа Шумана, принятого в 1971 г. Кроме того, в последнем выражалась поддержка миссии ООН под руководством Гуннара Ярринга [14, p. 283] - с самого начала и до сих пор Сообщества и ЕС последовательно выступают за разрешение конфликта именно с привлечением ООН.Документ Шумана в основном соответствовал резолюции № 242 СБ ООН. При этом он не содержал противоречий, связанных с несоответствием версий резолюции № 242 на разных языках (было не ясно, со всех ли территорий, оккупированных в 1967 г., должен отступить Израиль). Позиция государств-членов с тех пор состоит в том, что Израилю не принадлежат все территории, занятые в ходе войны июня 1967 г. [12, р. 125, n. 3]. Дальнейшее развитие подход Сообществ получил в декларации, принятой в Брюсселе в ноябре 1973 г., после окончания войны Судного дня. Наиболее значимым было требование 
уважения «законных прав палестинцев» [27]. Уже 1977 г. Европейский совет в Лондоне заявил, что «подлинное выражение» палестинской «национальной идентичности» и создание «очага для палестинского народа (курсив мой. - H. Г.)» $[28]^{2}-$ неотъемлемое условие разрешения конфликта. Таким образом, палестинская проблема все теснее связывалась с реализацией коллективных национальных прав палестинцев.

В 1980 г. была принята Венецианская декларация [30], легшая в основу современной позиции ЕС. Во-первых, государства-члены безоговорочно признали существование «палестинского народа, который сознает свое существование как таковой» [30]. Интересно, что Сообщества избрали очень «конструктивистский» подход к определению народа, в котором главную роль играет интерсубъективное согласие людей об их общности. Эта позиция звучала как ответ на знаменитое утверждение премьер-министра Израиля (1969-1974) Голды Меир: «Такого понятия, как палестинцы, не существовало. Когда был независимый палестинский народ с палестинским государством?.. Было не так, будто в Палестине был палестинский народ... и мы пришли и вытеснили их и отняли у них их страну. Их не существовало» (цит. по: [31, р.57]). С точки зрения конструктивизма любой народ является «изобретенным». Палестинский народ, действительно, мог еще не сложиться как социальный конструкт в прошлом, но сформировался позже, причем именно в ходе и под влиянием конфликта с «внешним врагом». Однако даже если к моменту провозглашения независимости Израиля (1948) не существовало палестинского народа, то это отнюдь не означает, что не существовало конкретных местных жителей Палестины, «вытеснение» которых вряд ли может быть законным только потому, что они не ощущали себя единой нацией. Во-вторых, Сообщества признали право палестинского народа «полностью реализовать свое право на самоопределение» [30]. Это было ключевым новшеством декларации. В-третьих, в этом контексте Сообщества призвали к всеобъемлющему подходу к достижению мира в регионе. Таким образом, они явно показали, что рассматривают Кэмп-Дэвидские соглашения (см., в частности: [32], см. также: [33]), слабо учитывавшие национальные права палестинцев, лишь как пробный шаг. В-четвертых, декларация предопределила позицию Сообществ и, позже, ЕС в отношении Иерусалима (этот вопрос также не регулировался Кемп-Дэвидскими договорами): статус города не должен меняться в одностороннем порядке, каждый должен иметь возможность свободно посещать святыни, находящиеся в нем [30].

Тем не менее в вопросе о наиболее полной реализации права палестинцев на самоопределение - возможности создания суверенного государства - Сообщества долго не могли выработать четкой позиции. На сессии Генеральной Ассамблеи (ГА) ООН 1980 г., специально посвященной палестинскому вопросу, все девять членов Сообществ воздержались при голосовании по резолюции [34], упоминавшей подобное право (США голосовали против) [35, с.231]. После того как Палестинский национальный совет (ПНС) в ноябре 1988 г. принял Декларацию независимости, провозглашавшую создание Государства Палестина [36], в рамках ЕПС было сделано заявление, призывавшее к продолжению переговоров и не разъяснявшее позицию государств-членов о признании государства. Позже действующий пред-

2 Любопытно, что такая же терминология («национальный очаг для еврейского народа») использовалась в декларации Бальфура 1917 г. (см.: [29, p. 16]). 
седатель ЕПС сказал, что последствия признания в рамках ЕПС вообще не обсуждались [37, p.380] $]^{3}$. При этом в декларации Европейского совета 1989 г. все же была выражена поддержка самоопределению палестинцев «вместе со всем, что из этого вытекает» [40, p. 13].

За годы мирного процесса Осло, который был поддержан Евросоюзом, ЕС удалось выработать общую позицию, в соответствии с которой разрешение конфликта предполагает создание суверенного палестинского государства. Впервые поддержка возможности его создания была прямо выражена в 1997 г. Европейский совет в Амстердаме призвал «народ Израиля признать право палестинцев на самоопределение, не исключая возможности создания государства» [41]. Более того, ЕС счел, что «создание жизнеспособного и мирного суверенного палестинского образования ['entity'] является лучшей гарантией безопасности Израиля» [41]. В декларации, принятой на заседании Европейского совета в Берлине в 1999 г. [42], ЕС призвал к продлению переходного периода, предусмотренного Соглашениями Осло (он должен был истечь 4 мая 1999 г.). Одновременно он подтвердил незыблемость «сохраняющегося и безусловного права палестинцев на самоопределение, включая возможность создания государства» [42]. ЕС заявил и о том, что «с нетерпением ожидает скорого выполнения этого права» [42]. Подчеркивалось, что оно не подлежало вето с чьейлибо стороны. К характеристикам будущего палестинского государства добавлялся его демократический характер. Наконец, ЕС выразил готовность рассмотреть вопрос о признании этого государства [42]. На встрече Европейского совета в Севилье в 2002 г. была резюмирована цель ЕС в разрешении конфликта - «два государства, существующие рядом друг с другом в безопасных и признанных границах, имеющие нормальные отношения со своими соседями» [43, р.35]. Отмечалась возможность небольших и согласованных сторонами изменений границ, существовавших до войны 1967 г. Тогда же ЕС повторил, что необходимо найти «справедливое решение» о статусе Иерусалима и «справедливое, жизнеспособное и согласованное решение проблемы палестинских беженцев» [43, р.35]. В 2009 г. ЕС вновь подтвердил, что Иерусалим должен быть столицей обоих государств, что «никогда не признавал аннексию Восточного Иерусалима» Израилем, и призвал его вновь разрешить работу «палестинских институтов» в городе [44].

ЕС приветствовал Арабскую мирную инициативу [45], выдвинутую на саммите Лиги арабских государств (ЛАГ) в 2002 г. и подтверждающуюся ЛАГ с тех пор. ЕС стал членом квартета международных посредников по Ближнему Востоку

3 В 1988 г., после принятия Декларации независимости, Государство Палестина признали в том числе Болгария, Венгрия, Польша, Румыния, Чехословакия (страны социалистического лагеря), а также Мальта и Кипр - будущие члены ЕС [38]. Конечно, провозглашение Палестины в 1988 г. происходило в совершенно ином контексте, до учреждения палестинского самоуправления в виде Палестинской Администрации на части оккупированных палестинских территорий (ОПТ), и имело еще меньшее отношение к реальному суверенитету, чем сейчас. Большее значение имеет процесс признания Палестины в рамках ООН с 2011 г. В ноябре 2012 г. Палестина получила статус государства-наблюдателя, не являющегося членом, при ООН [39]; в январе 2013 г. Палестинская Администрация (ПА) изменила свое официальное название на «Государство Палестина». ЕС продолжает использование термина «Палестинская Администрация», хотя в его неофициальных материалах все чаще употребляются новое самоназвание «Государство Палестина» или сокращенное название «Палестина». Последнее, однако, не означает признания палестинского государства со стороны ЕC, поскольку единая позиция на этот счет отсутствует, а отдельные государства-члены принимают соответствующие решения самостоятельно. 
и поддержал дорожную карту квартета с момента ее разработки (2002-2003) (см. промежуточный вариант: [46]; окончательный вариант: [47]), в которой сам сыграл заметную роль. Эти документы в целом отразили позицию ЕС, соответствовали принципам Мадридской конференции 1991 г., в том числе принципу «земля в обмен на мир», и цели создания палестинского государства. Они стали элементами подхода ЕС к конфликту [48].

Как показало развитие событий с того момента, когда в сентябре 2011 г. председатель ПА и Исполкома ООП Махмуд Аббас обратился в ООН с просьбой о признании суверенного палестинского государства и его принятии в состав Организации, ЕС в целом (а не отдельные государства-члены) пока считает, что полноценное палестинское государство может быть создано лишь в итоге мирных переговоров. До 2011 г. ЕС несколько раз намекал на возможность определения крайнего срока, по наступлении которого такое государство могло бы быть признано. Так, бывший Верховный представитель по ОВПБ, Генеральный секретарь Совета ЕC Х. Солана высказывал мысль о том, что по наступлении определенного крайнего срока СБ $\mathrm{OOH} \mathrm{должна} \mathrm{принять} \mathrm{резолюцию,} \mathrm{в} \mathrm{которой} \mathrm{были} \mathrm{бы} \mathrm{урегулированы} \mathrm{все} \mathrm{окон-}$ чательные параметры, и должно было быть провозглашено палестинское государство, которое бы стало полноправным членом ООН (см., напр.: [49]).

Тем не менее в сентябре 2011 г. Верховный представитель ЕС по иностранным делам и политике безопасности (ИДПБ) Кэтрин Эштон выступила лишь за продолжение переговорного процесса. Она поддержала модель, изложенную в заявлении квартета и предполагающую завершение нового раунда переговоров к концу 2012 г. [50-52]. К декабрю 2012 г. переговоры вновь не дали ожидаемого результата, а Палестина получила статус государства-наблюдателя при ООН [39]. Тогда ЕС лишь смог повторно высказать свою поддержку переговорному решению, констатировать «новый статус» Палестины и призвать к тому, чтобы в этом статусе она действовала «конструктивно», т. е. так, чтобы не наносить ущерба перспективам соглашения с Израилем [53]. После того как 30 декабря 2014 г. в СБ ООН была отклонена резолюция, предлагавшая конкретные временные рамки для приема Палестины в ООН в качестве полноправного члена и для окончания конфликта, Верховный представитель ЕС по ИДПБ Федерика Могерини также смогла только подтвердить, что ЕС традиционно поддерживает переговоры на основе в целом старых параметров мирного процесса [54].

Наконец, два важных уточнения были внесены в позицию ЕС в декабре 2013 г. Во-первых, он, наконец, обозначил свое отношение к возможности формирования в бывшей подмандатной Палестине единого государства для евреев и арабов вместо сосуществования двух государств. ЕС отверг этот вариант, сочтя, что «реальность существования одного государства была бы несовместима с легитимными надеждами обеих сторон на суверенитет и демократию» [55].

Во-вторых, было заявлено, что если Израиль и палестинцы достигнут окончательного соглашения, то «ЕС предоставит беспрецедентный пакет политической и экономической помощи, а также помощи в области безопасности обеим сторонам» - в этом случае ЕС свяжет с ними «Специальное привилегированное партнерство» (СПП), предполагающее «расширенный доступ к европейским рынкам, более тесные культурные и научные связи, облегчение торговли и инвестиций... поощрение деловых контактов. Будут также предложены усиленный политический 
диалог и сотрудничество в сфере безопасности...» [55]. Позже ЕС несколько уточнил свою инициативу. Он выразил готовность оказывать будущему палестинскому государству поддержку в сферах экономики и безопасности, способствовать участию Египта и Иордании в его стабилизации, чтобы снизить угрозы, которые оно могло бы создать для Израиля. ЕС также озвучил готовность оказать денежную помощь тем палестинским беженцам, которые не будут требовать реализации своего права на возвращение. Как говорят представители ЕС, он предложил Израилю и палестинцам такой уровень отношений, который является «лучшим вариантом после членства» и соответствует его партнерству с Норвегией и Швейцарией [56]. СПП стало самым важным проектом европеизации конфликта, когда-либо выдвигавшимся ЕС (см. также: [57, с. 571-572]).

Итак, сложившаяся позиция ЕС предполагает, что решение конфликта возможно только через достижение по итогам переговоров мирного сосуществования Израиля и палестинского государства. ЕС выразил готовность оказать значительную поддержку сторонам после достижения окончательного соглашения. Вместе с тем ЕС оказался не готов ни признать провозглашенное Государство Палестина, ни рассмотреть возможные альтернативные сценарии общего решения конфликта (например, создание единого государства для евреев и арабов).

\section{Позиция ЕС в отношении защиты прав человека и соблюдения международного гуманитарного права}

Вторая составляющая позиции ЕС касается защиты прав человека и соблюдения международного гуманитарного права. Официальная приверженность этим правам в контексте конфликта выражалась Сообществами также начиная с 1970-х годов. Государства-члены, конечно, осуждали акты вооруженного насилия палестинцев против гражданских лиц, но в то же время обращали повышенное внимание на нарушения со стороны Израиля, в частности на строительство еврейских поселений на оккупированных палестинских территориях [8, p. 14]. В многочисленных декларациях Сообществ и ЕС указывалось, что эти поселения не только подрывают перспективы разрешения конфликта, но и незаконны в соответствии с МГП, в частности с четвертой Женевской конвенцией о защите гражданского населения во время войны 1949 г. (см., напр.: [30; 48]; см. также: [8, p. 14]). Осуждая строительство поселений, ЕС считает незаконными и все соответствующие шаги Израиля на оккупированных палестинских территориях (снос домов, экспроприации, строительство контрольно-пропускных пунктов, дорог, предназначенных только для израильтян, и др.) [8, p. 14]. Во время переходного периода, предусмотренного процессом Осло, ЕС избегал острой критики поселенческой активности Израиля, однако с 2000 г. он все более активно ее осуждает и призывает к демонтажу поселений [8, p. 14]. В последнее время в дискурсе ЕС поселенческая активность Израиля все больше рассматривается как главный фактор, который угрожает сделать недостижимым само формирование полноценного палестинского государства $[48 ; 58]$.

Тем не менее практическое подкрепление этой позиции ЕС оказалось запоздалым и ограниченным. Так, лишь в июле 2013 г. ЕС решился на то, чтобы прямо запретить с 2014 г. направление своих финансовых средств на израильские 
поселенческие проекты на ОПТ [59]. В 2014 г. также было решено поставить под запрет импорт в ЕС молочной и другой животной продукции из поселений с 2015 г. [60].

В особенности с момента начала первой интифады в 1987 г. критике Сообществ подверглись и другие нарушения, связанные с применением израильтянами силы и различных "репрессивных мер» для подавления палестинского восстания [40, p. 13] (см. также: [13, p.9]). Уже в это время Европейский совет поддержал право жителей ОПТ на проведение свободных выборов (в том числе и в Восточном Иерусалиме, против чего выступал Израиль) [40, p. 13-14]. В ходе второй интифады (2000-2005) ЕС призывал прекратить нарушения прав человека и МГП с обеих сторон, осуждая как теракты палестинских смертников, так и непропорциональное использование силы Израилем и случаи внесудебных убийств палестинцев (см., напр.: [61]). Ту же позицию он занял в отношении ситуации, сложившейся с сектором Газа. После вывода из сектора к 2005 г. израильских войск и поселений и взятия в 2007 г. Газы под контроль движением ХАМАС произошли три крупных вооруженных конфликта - израильские операции «Литой свинец» в декабре 2008 - январе 2009 гг., «Облачный столп» в ноябре 2012 г. и «Нерушимая скала»в июле-августе 2014 г. ЕС осуждал запуски ракет из Газы по израильским городам, признавая опасения Израиля в области безопасности. Но одновременно он предупреждал Израиль о недопустимости использования силы против гражданского населения и требовал полного снятия ограничений на доступ в Газу, которые во многом представлялись как коренная причина насилия (см., напр.: [62; 63; 53]).

EC с самого начала осудил строительство Израилем стены, отделяющей его от Западного берега реки Иордан, которое, по мнению критиков, противоречит МГП и нарушает права палестинцев (в том числе де-факто ведет к аннексии части Западного берега). Так, в Севильской декларации отражено убеждение ЕС в том, что «стены не принесут мира» в регион [43, р. 36].

Наконец, в отношении присоединения Палестины к Международному уголовному суду (МУС), деятельность которого Евросоюз в целом поддерживает, позиция ЕС оказалась невнятной. Так, в 2011 г. К.Эштон, по некоторым сообщениям, советовала палестинским дипломатам не пользоваться рядом привилегий, которые дает статус государства-наблюдателя при ООН, - в частности, не обращаться в МУС [64]. Очевидно, именно так ЕС понимал «конструктивный» подход ПА в случае обретения этого статуса. В июне 2013 г. ЕС намекнул Израилю на то, что если его поселенческая активность помешает развитию переговоров, то он поддержит членство Палестины в МУС и дальнейшие действия по признанию Палестины в системе ООН [65]. Однако после провала переговоров 2013-2014 гг. и конфликта между Израилем и ХАМАС в 2014 г. ЕС в целом оказался не готов одобрить присоединение Палестины к МУС, которое произошло 1 апреля 2015 г.

Европейские сообщества и ЕС, таким образом, стремились обеспечить защиту прав человека и соблюдение МГП с обеих сторон. Тем не менее по ряду важных вопросов (еврейские поселения на ОПТ, оценка израильской блокады Газы с точки зрения международного права, присоединение Палестины к МУС) позиция ЕС оказывалась недостаточно последовательной или ясной. В целом упорная поддержка со стороны ЕС цели сосуществования двух государств в сложившихся условиях все меньше отвечает его ориентиру по защите прав человека, поскольку пока суще- 
ствующая модель мирного процесса не обеспечила ни существование стабильного и демократического Палестинского государства, ни соблюдение прав палестинских беженцев и арабского меньшинства в Израиле, ни защиту безопасности израильтян (см.: $[8$, p. 75]).

\section{Позиция ЕС в отношении ООП и ХАМАС}

Особую важность имеет позиция ЕС в отношении тех политических акторов, которые претендуют на то, чтобы представлять интересы палестинцев. Исторически подход Европейских сообществ и ЕС можно назвать инклюзивным. Среди государств западного блока члены Сообществ одними из первых признали важную роль Организации освобождения Палестины. Уже в 1979 г. ООП была прямо упомянута в речи действующего председателя ЕПС - министра иностранных дел Ирландии Майкла О’Кеннеди [66]. В Венецианской декларации Сообщества признали, что «ООП... необходимо будет подключить к переговорам», и выразили желание вступить в диалог со всеми акторами, вовлеченными в конфликт (можно считать, что это относилось и к ООП) [30]. В обоих документах фактически содержалась мысль о том, что без ООП разрешение конфликта в любом случае было бы невозможным. В 1987 г. государства-члены выразили недовольство решением США закрыть постоянную миссию ООП при ООН, подчеркнув его незаконность [37, p.393-394]. После того как в 1993-1994 гг. произошло взаимное признание Израиля и ООП и была создана Палестинская Администрация, ЕС продолжал сотрудничать с ООП и ПА как законными представителями палестинского народа. Даже в разгар второй интифады ЕС выступал против маргинализации председателя ПА и Исполкома ООП Ясира Арафата (в противоположность США и Израилю) и тем более против применения к нему насилия. Например, Х. Солана, разделяя позицию Франции, настаивал тогда, что Арафат - «легитимный лидер палестинского народа», необходимый для поиска мирного решения (цит. по: [67, с. 345]).

Однако официальная позиция ЕС в отношении другой палестинской организации - движения ХАМАС - оказалась противоположной. В 2006 г. связанный с ХАМАС блок выиграл демократические выборы в Палестинский законодательный совет (ПЗС), и с 2007 г. ХАМАС контролирует сектор Газа, таким образом претендуя на роль представителя значительной части палестинцев. В 2001 г. в список террористических организаций ЕС было внесено военное крыло организации бригады 'Изз ад-Дина ал-Кассама [68], в 2003 г. - все движение XАMAC [69] сле победы ХАМАС на выборах 2006 г. ЕС поддерживает три условия, выдвинутые квартетом по Ближнему Востоку, для возможности диалога с движением и получения его правительством помощи доноров. Они включают: «отказ от насилия, признание Израиля и принятие предыдущих соглашений и обязательств, включая дорожную карту» $[71]^{5}$. ХАМАС не принял эти условия в полной мере.

Тем не менее за период с 2006 г. ЕС, не отказавшись от критериев квартета, все же иногда проявлял некоторую гибкость. Так, когда в июне 2014 г. было сформиро-

${ }^{4}$ В России ХАМАС не входит в Единый федеральный список организаций, в том числе иностранных и международных организаций, признанных в соответствии с законодательством Российской Федерации террористическими (на 25 октября 2016 г.) [см.: 70].

${ }^{5}$ Россия не поддержала полную изоляцию движения ХАМАC. 
вано единое независимое (но одобренное ФАТХ и ХАМАС) палестинское правительство, ЕС продолжил работать с ним.

Наконец, 17 декабря 2014 г. - спустя 11 лет после внесения ХАМАС в список террористических организаций ЕС - Суд общей юрисдикции ЕС решил, что ХАМАС должен быть из списка удален, поскольку, как особо подчеркнул суд, движение было включено в него не на основе тщательного изучения Советом ЕС всех необходимых документов, а всего лишь (!) на основе «сведений... из прессы и интернета» [72]. В то же время решение суда не касалось содержательного вопроса о том, следует ли отнести ХАМАС к террористическим организациям, а лишь указало на процессуальные нарушения Совета. Совет ЕС подал апелляцию на решение Суда, и до тех пор, пока апелляция не будет рассмотрена, решение не вступит в силу (см.: [73]).

Таким образом, Европейские сообщества смогли пойти на достаточно смелый шаг, признав важность ООП для поиска решения конфликта. Однако позже ЕС решил применить в отношении ХАМАС противоположную логику исключения и давления.

\section{Некоторые особенности позиции ЕС в отношении конфликта}

Позиция Сообществ, унаследованная ЕС, оказалась в целом более близкой взгляду палестинской ООП (и Движения палестинского национального освобождения - ФАТХ) на конфликт. Оценивая факторы, которые повлияли на формирование подобной позиции, стоит отметить, что едва ли можно объяснить ее исходя в основном из эгоистических материальных интересов ЕС и сводить ее значение лишь к их декларативному оправданию ${ }^{6}$. С теоретической точки зрения выделение интересов международного актора всегда проблематично. В данном случае не следует делать упор исключительно на потребностях государств-членов в арабской нефти или страхе перед палестинским терроризмом, недовольством европейских арабов и мусульман, а также эскалацией биполярного противостояния в период ЕПС.Конечно, Сообщества не имели такой международной ответственности и ставок в конфликте, как США (см. подр.: [9]), и им могло быть удобно выдвигать нереалистичные планы, а затем «прятаться» за американское вето в СБ ООН.Все эти соображения играли определенную роль - но нельзя игнорировать и важность связей с Израилем и США, которым более «пропалестинская» позиция, безусловно, вредила. Не стоит забывать и о чувстве исторической ответственности перед евреями. В конечном счете все решал выбор между конкурирующими интерпретациями интересов. Исторически позиция Сообществ, а затем ЕС, которая оказалась столь устойчивой до настоящего времени, означала для них не просто удачный «прагматичный» маневр для привлечения симпатий арабских государств. Она напрямую касалась самоидентификации Сообществ и ЕС на международной арене, «гордости за политику, которая была фактически первым примером... общей внешней политики [EC]» [11, с. 199], а также за то, что государствам-членам ЕС их собственный подход казался более «сбалансированным», «многосторонним» и выгодно отличающимся от подхода США [11, p. 198-200]. Нужно также учесть,

${ }^{6}$ О неполноте объяснений ближневосточного мирного процесса, в которых акцентируются лишь якобы самоочевидные интересы (связанные с межгосударственными противоречиями, внутренним лоббизмом), писал также Р. Даннройтер [11]. 
что сейчас экономические и политические ставки ЕС в конфликте, его ответственность и ожидания всех акторов, направленные на него, конечно, гораздо выше, чем в период ЕПС.

Наконец, нужно отметить три общих противоречия, связанные с позицией ЕС. Во-первых, в ней нашли определенное отражение его базовые нормы мир, свобода, демократия, правопорядок, права человека (см. об этих нормах: [74, p. 242]). Акцент ЕС на роли ООН, квартета и на разрешении конфликта путем переговоров указывает и на важность для него принципа мультилатерализма (многосторонности) (см. о мультилатерализме: [75, р.316; 76]). Однако эти ценности, конечно, могут интерпретироваться по-разному. В данном случае ЕС имел два ориентира, связанных с соответствующими ценностями и имеющих основания в международном праве, - самоопределение двух народов и защита прав человека и МГП.Нужно подчеркнуть, что первый ориентир связан прежде всего с коллективными, а второй - с индивидуальными правами. Примерно с того момента, как Сообщества перестали считать палестинскую проблему исключительно нарушением прав конкретных людей - беженцев, т. е. еще с 1970-х годов, первый ориентир стал преобладать. Особенно это проявилось на современном этапе, когда главной целью стало разрешение конфликта через сосуществование двух государств. Тем не менее одной из наиболее глубоких проблем в политике ЕС является то, что две выделенные линии его предпочтений в сложившейся ситуации все больше входят в противоречие друг с другом [8, р.75].

Во-вторых, в период ЕПС, а также в начале современного этапа (1990-е) Сообщества и ЕС являлись «пионером», выдвигавшим смелые и оригинальные подходы к разрешению конфликта. Они явно «обгоняли» развитие позиции США. Это касалось, например, диалога с ООП и возможности создания палестинского государства - принципов, которые затем получат широкое признание в международном сообществе (см., напр.: [77, p. 25, 27; 10, p. 106-107]). Однако примерно с 2000-х годов ЕС делал меньше оригинальных и независимых предложений.

В-третьих, в позиции ЕС можно заметить несколько неясностей, «умолчаний», или «серых зон». Среди важнейших - возможность диалога с ХАМАС; нечеткая характеристика блокады сектора Газы с точки зрения международного права (см., напр.: [78, р. 2-3]); расплывчатое содержание «беспрецедентного пакета помощи» обеим сторонам в случае разрешения конфликта; поддержка строительства палестинского государства и одновременно растущие опасения по поводу его осуществимости; непоследовательная позиция в отношении членства Палестины в МУС; невнятная позиция по отношению к «еврейскому» характеру Государства Израиль; малое внимание к практическому поиску устойчивого решения проблем палестинских беженцев и арабского меньшинства в Израиле, а также к истокам конфликта до 1967 г., особенно к событиям 1948 г., приведшим к исходу палестинских арабов с мест их жительства (араб. «ан-Накба» - «Катастрофа»).

\section{Заключение}

Таким образом, за годы развития ЕПС и ОВПБ сложилась относительно единая позиция Евросоюза в отношении конфликта, которая свидетельствовала о постепенном нарастании внутренней общности, сближении внутри ЕС разных интер- 
претаций «верного» и «справедливого» подхода к его разрешению. Сама выработка относительно единого взгляда на столь сложную проблему, в котором чаще всего отражалось движение всех членов к компромиссу и заинтересованность в вопросе, может считаться для ЕС достижением. Однако это, конечно, не исключает разногласий между государствами-членами и органами Евросоюза, а также отмеченной внутренней противоречивости, недостатка смелости и ясности в самой его позиции.

Очевидно, что все эти проблемы сказываются как на влиятельности ЕС в конфликте, так и на перспективах разрешения самого конфликта. Причины отмеченных сложностей состоят, во-первых, в типичных для ЕС особенностях - внутренних разногласиях и имидже недостаточно последовательного актора в глазах противоборствующих сторон и других внешних игроков. Во-вторых, как было показано, позиция ЕС противоречива в содержательном плане. Она слабо учитывает тенденции, имеющиеся в конфликтном регионе и подрывающие эффективность поддерживаемой ЕС модели мирного процесса и исключения ХАМАС.

Соответственно, позиция ЕС сможет стать более эффективной лишь в случае, если она будет, во-первых, более последовательной, во-вторых, более открыта для альтернативных решений. Последние могли бы предполагать сдвиг акцентов с попыток отыскать баланс между коллективными национальными притязаниями израильтян и палестинцев - попыток, терпящих провал уже несколько десятилетий, - на стремление гарантировать фундаментальные права для каждого человека, живущего в бывшей подмандатной Палестине, в независимости от его групповой идентичности. Подобный вариант лучше продемонстрировал бы приверженность ЕС собственным ценностям - тому, что преодоление конфликтующих групповых идентичностей, которое во многом стало смыслом европейской интеграции, может быть достижимым и на Ближнем Востоке.

\section{Литература}

1. Smith M. Institutionalization, Policy Adaptation and European Foreign Policy Cooperation // European Journal of International Relations. 2004. Vol. 10, N 95. P. 95-136.

2. Ambos A., Von Behr I. The Middle East Peace Process // European Foreign Policy: From Rhetoric to Reality? / ed. by D. Mahncke, A. Ambos, C. Reynolds. Brussels: Presses Interuniversitaires Européennes, 2004. P. 293-316.

3. Second Report on European Political Co-operation on Foreign Policy. Copenhagen. 1973. July 23. Annex. URL: http://www.cvce.eu/content/publication/1999/1/1/8b935ae1-0a38-42d4-a97e-088c63d54b6f/ publishable_en.pdf (дата обращения: 04.06.2016).

4. Declaration on European Identity. Copenhagen. 1973. December 14. URL: http://www.cvce.eu/obj/ Declaration_on_European_Identity_Copenhagen_14_December_1973-en-02798dc9-9c69-4b7d-b2c9f03a8db7da32.html (дата обращения: 04.06.2016).

5. Santa Maria Da Feira European Council. 2000. June 19-20. Presidency Conclusions. Annex V.Common Strategy of the European Union on the Mediterranean Region. URL: http://www.europarl.europa.eu/ summits/fei2_en.htm an5 (дата обращения: 04.06.2016).

6. A Secure Europe in a Better World. European Security Strategy. Brussels. 2003. December 12. URL: http://www.consilium.europa.eu/uedocs/cmsUpload/78367.pdf (дата обращения: 05.06.2016).

7. Shared Vision, Common Action: A Stronger Europe. A Global Strategy for the European Union's Foreign And Security Policy. 2016. June. URL: https:/europa.eu/globalstrategy/sites/globalstrategy/files/ eugs_review_web.pdf (дата обращения: 22.08.2016).

8. Tocci $\bar{N}$. Active but Acquiescent: the EU's Response to the Israeli Military Offensive in the Gaza Strip. Brussels: Euro-Mediterranean Human Rights Network, 2009. 89 p.

9. Allen D., Smith M. Europe, the United States and the Middle East: a Case Study in Comparative Policy Making // Journal of Common Market Studies. 1983. Vol.22, N 2. P. 125-146. 
10. Ginsberg R. H. The European Union in International Politics. Baptism by Fire. Boston: Rowman \& Littlefield, 2001. $307 \mathrm{p}$.

11. Dannreuther R. Understanding the Middle East Peace Process: A Historical Institutionalist Approach // European Journal of International Relations. 2011. Vol. 17, N2. P. 187-208.

12. Müller P. The Europeanization of France's Foreign Policy towards the Middle East Conflict - from Leadership to EU Accommodation // European security. 2013. Vol.22, N 1. P.113-128.

13. Pardo S., Peters J. Uneasy Neighbours: Israel and the European Union. Plymouth: Lexington Books, 2010. xii+155 p.

14. Sachar H. M. Israel and Europe. An Appraisal in History. New York: Vintage Books; Toronto: Random House of Canada Limited, 2000. xiii, 398 p.

15. Заславская Н. Г. Эволюция институционального баланса в ЕС в контексте европейской интеграции // Клио. 2015. № 3 (99). С. 155-160.

16. Морозов В.Е. Европа: ориентация во времени и пространстве // Россия в глобальной политике. 2008. Т. 6, № 3. С. 78-89.

17. Романова T. А. Империя норм Регулятивная экспансия ЕС и ее пределы // Россия в глобальной политике. 2013. Т. 11, № 1. С. 182-192.

18. Мишальченко Ю. В., Изотов А.В. Основные факторы формирования отношения Европейского союза к процессам евразийской интеграции // Евразийская интеграция: экономика, право, политика. 2014. № 16. С. 26-31.

19. Ткаченко С. Л. Концепция энергетической сверхдержавы и отношения Российской Федерации и Евросоюза в области энергетики // Экономика качества. 2014. № 8. С. 84-94.

20. Современные отношения России и Европейского союза: десять лет после подписания Соглашения о партнерстве и сотрудничестве // Мат-лы Междунар. науч. конф., Факультет международных отношений СПбГУ / отв. ред. К. К. Худолей. СПб.: Изд-во С.-Петерб. ун-та, 2005. 178 с. (Библиотека европейских исследований; вып. 18).

21. Зыкова О.А. Отношения Европейского Союза и Израиля в контексте арабо-израильского конфликта // Востоковедный сборник. М.: Институт изучения Израиля и Ближнего Востока, 2003. Вып. 5. С. 152-165.

22. Колобов А.О. Позиция Евросоюза по отношению к Израилю и Палестинской Национальной Автономии в рамках ближневосточного мирного процесса // Вестн. Нижегородского ун-та им. Н.И. Лобачевского. 2009. № 3. С. 224-226.

23. Крылов А.В. Противодействие стран Евросоюза поселенческой политике Израиля: мифы и реальность // Вестн. МГИМО-Университета. 2014. № 6 (39). С. 161-173.

24. Кутрашев Д. К. Посредническая миссия ЕС в палестино-израильском конфликте // Вся Евpoпа. 2012. № 3 (64). URL: http://www.alleuropa.mgimo.ru/posrednicheskaya-missiya-es-v-palestino-izrailjskom-konflikte (дата обращения: 06.06.2016).

25. Голубев Д. С. Концептуальные основы посредничества США в урегулировании арабо-израильского конфликта на современном этапе: дис. ... канд. полит. наук. СПб., 2010. 286 с.

26. Совет Безопасности Организации Объединенных Наций. Резолюция 242. 1967. 22 ноября. URL: http://daccess-dds-ny.un.org/doc/RESOLUTION/GEN/NR0/241/18/IMG/NR024118.pdf?OpenElement (дата обращения: 07.06.2016).

27. Declaration of the Nine Foreign Ministers on the Situation in the Middle East. Brussels. 1973. November 6. URL: http://www.cvce.eu/content/publication/1999/1/1/a08b36bc-6d29-475c-aadb-0f71c59dbc3e/ publishable_en.pdf (дата обращения: 07.06.2016).

28. London European Council. 1977. June 29-30. Presidency Conclusions. Statement on the Middle East. URL: http://aei.pitt.edu/1410/1/London_june_1977.pdf (дата обращения: 08.06.2016).

29. The Balfour Declaration. November 2, 1917 // The Israel-Arab Reader. A Documentary History of the Middle East Conflict / eds W. Laqueur, B. Rubin. New York: Penguin Books, 2008. P. 16.

30. The European Council. Venice Declaration. 1980. June 13. URL: http://eeas.europa.eu/mepp/docs/ venice_declaration_1980_en.pdf (дата обращения: 08.06.2016).

31. Kimmerling B., Migdal J. S. Introduction to The Palestinian People: A History // Postzionism: A Reader / ed. by L. J. Silberstein. New Brunswick: Rutgers University Press, 2008. P. 56-60.

32. Camp David Summit Meetings: Frameworks for Peace. 1978. September 17 // The Israel-Arab Reader. A Documentary History of the Middle East Conflict / eds W. Laqueur, B. Rubin. New York: Penguin Books, 2008. P. 222-227.

33. Egypt and Israel: Peace Treaty. 1979. March 26 // The Israel-Arab Reader. A Documentary History of the Middle East Conflict / eds W.Laqueur, B. Rubin. New York: Penguin Books, 2008. P.227228. 
34. United Nations General Assembly Resolution 35/169. Question of Palestine. 1980. December 15. URL: http://www.un.org/documents/ga/res/35/a35r169e.pdf (дата обращения: 09.06.2016).

35. Пьрлин Е. Д. Сто лет противоборства: Генезис, эволюция, современное состояние и перспективы решения палестинской проблемы. М.: РОССПЭН, 2001. 480 с.

36. Palestine National Council: Declaration of Independence. 1988. November 15 // The Israel-Arab Reader. A Documentary History of the Middle East Conflict / eds W. Laqueur, B. Rubin. New York: Penguin Books, 2008. P. 354-358.

37. Dehousse R. European Political Cooperation 1 July 1987 - 31 December 1988 // European Journal of International Law. 1990. Vol. 1, N 1. P.378-399.

38. Diplomatic Relations // Permanent Observer Mission of The State of Palestine to the United Nations. 2014. URL: http://palestineun.org/about-palestine/diplomatic-relations/ (дата обращения: 10.06.2016).

39. United Nations General Assembly Resolution 67/19. Status of Palestine in the United Nations. 2012. November 29. URL: http://www.un.org/en/ga/search/view_doc.asp?symbol=A/RES/67/19 (дата обращения: 17.06.2016).

40. Madrid European Council. 1989. June 26-27. Presidency Conclusions. Declaration on the Middle East. P. 12-14. URL: http://aei.pitt.edu/1453/1/Madrid_june_1989.pdf (дата обращения: 10.06.2016).

41. Amsterdam European Council. 1997. June 16-17. Presidency Conclusions. Annex III. URL: http://www. consilium.europa.eu/uedocs/cms_data/docs/pressdata/en/ec/032a0006.htm (дата обращения: 10.06.2016).

42. Berlin European Council. 1999. March 24-25. Presidency Conclusions. URL: http://www.consilium. europa.eu/uedocs/cms_data/docs/pressdata/en/ec/ACFB2.html (дата обращения: 11.06.2016).

43. Seville European Council. 2002. June 21 and 22. Presidency Conclusions. Declaration on the Middle East. P.35-36. URL: http://www.consilium.europa.eu/ueDocs/cms_Data/docs/pressData/en/ec/72638.pdf (дата обращения: 12.06.2016).

44. Council Conclusions on the Middle East Peace Process. Brussels. 2009. December 8. URL: http:// eeas.europa.eu/delegations/israel/press_corner/all_news/news/2009/20091208_01_en.htm (дата обращения: 16.06.2016).

45. Majlis jaami'at ad-duwal al-'arabiyya. Mubaadarat as-salaam al-'arabiyya. Bairut. 2002. 28 mars. URL: http://www.nad-plo.org/atemplate.php?id=88 (дата обращения: 06.03.2014).

46. Communiqué issued by the Quartet. New York. 2002. September 17. URL: http://unispal.un.org/ unispal.nsf/fdc5376a7a0587a4852570d000708f4b/54c9e0a5f8ccbd2b85256c3700653ea4?OpenDocument (дата обращения: 16.06.2016)

47. A Performance-Based Roadmap to a Permanent Two-State Solution to the Israeli-Palestinian Conflict. Washington, DC. 2003. April 30. URL: http://www.mfa.gov.il/MFA/Peace+Process/ Guide+to+the+Peace+Process/A+Performance-Based+Roadmap+to+a+Permanent+Two-Sta.htm （дата обращения: 16.06.2016).

48. Council Conclusions on the Middle East Peace Process. Brussels. 2012. May 14. URL: http://www. eu-un.europa.eu/articles/en/article_12170_en.htm (дата обращения: 16.06.2016).

49. Solana J. Europe in the World. Boston. 2009. September 17. URL: http://www.consilium.europa.eu/ uedocs/cms_data/docs/pressdata/EN/discours/110218.pdf (дата обращения: 16.06.2016).

50. Ashton C. Press Briefing. 2011. September 23. URL: http://ec.europa.eu/avservices/video/player. cfm?sitelang=en\&ref=79846 (дата обращения: 17.06.2016).

51. Quartet Statement. New York. 2011. September 23. URL: http://www.un.org/news/dh/infocus/middle_east/quartet-23sep2011.htm (дата обращения: 17.06.2016).

52. Rettman A. EU Pitches Counter-Offers to Palestinian Statehood Bid // EUobserver. 2011. September 24. URL: http://euobserver.com/24/113725 (дата обращения: 17.06.2016).

53. Council Conclusions on the Middle East Peace Process. Brussels. 2012. December 10. URL: http:// www.consilium.europa.eu/uedocs/cms_Data/docs/pressdata/EN/foraff/134140.pdf (accessed: 18.06.2016).

54. Mogherini F. Statement on the UN Security Council Vote on the MEPP / European Union Delegation to the United Nations. 2014. December 30. URL: http://eu-un.europa.eu/articles/en/article_15912_en.htm (дата обращения: 18.06.2016).

55. Council Conclusions on the Middle East Peace Process. Brussels. 2013. December 16. URL: http://www. consilium.europa.eu/uedocs/cms_data/docs/pressdata/EN/foraff/140097.pdf (дата обращения: 18.06.2016)

56. Ahren R. EU ready to pay Palestinians who renounce right of return // The Times of Israel. 2014. March 24. URL: http://www.timesofisrael.com/eu-ready-to-pay-palestinians-who-renounce-right-of-return/ (дата обращения: 18.06.2016).

57. Гудалов Н.Н. Проблемы применения Европейским союзом принципа кондициональности для разрешения палестино-израильского конфликта (на опыте мирных переговоров 2013-2014 гг.) // Политика и общество. 2014. № 5. С. 568-578. DOI: 10.7256/1812-8696.2014.5.12267. 
58. Macintyre D. EU on Verge of Abandoning Hope for a Viable Palestinian State // The Independent. 2012. January 12. URL: http://www.independent.co.uk/news/world/middle-east/eu-on-verge-of-abandoning-hope-for-a-viable-palestinian-state-6288336.html (дата обращения: 19.06.2016).

59. Guidelines on the eligibility of Israeli entities and their activities in the territories occupied by Israel since June 1967 for grants, prizes and financial instruments funded by the EU from 2014 onwards. 2013. July 19. URL: http://eeas.europa.eu/delegations/israel/documents/related-links/20130719_guidelines_on_eligibility_of_israeli_entities_en.pdf (дата обращения: 19.06.2016).

60. Mezzofiore G. EU Bans Israeli Dairy Products made in Occupied West Bank Settlements form January // International Business Times. 2014. October 10. URL: http://www.ibtimes.co.uk/eu-bans-israelidairy-products-made-occupied-west-bank-settlements-january-1469454 (дата обращения: 19.06.2016).

61. Copenhagen European Council. 2002. December 12-13. Presidency Conclusions. URL: http://www. consilium.europa.eu/ueDocs/cms_Data/docs/pressData/en/ec/73842.pdf (дата обращения: 19.06.2016).

62. Council Conclusions on Middle East Peace Process. Brussels. 2009. January 26-27. URL: http:// www.consilium.europa.eu/uedocs/cms_Data/docs/pressdata/en/gena/105545.pdf (дата обращения: 19.06.2016).

63. Council Conclusions on Middle East Peace Process. Brussels. 2012. November 19. URL: http:// www.consilium.europa.eu/uedocs/cms_Data/docs/pressdata/EN/foraff/133604.pdf (дата обращения: 19.06.2016).

64. Ettaba S. S. Palestinian Statehood Bid Victim of Double Standards // Middle East Online. 2011. September 21. URL: http://www.middle-east-online.com/english/?id=48143 (дата обращения: 19.06.2016).

65. Yanover Y. EU: If Netanyahu Builds in Jerusalem, We'll Back PA in Hague // The Jewish Press. 2013. June 6. URL: http://www.jewishpress.com/news/breaking-news/eu-if-netanyahu-builds-in-jerusalem-wellback-pa-in-hague/2013/06/06/ (дата обращения: 19.06.2016).

66. O'Kennedy M. Speech in New York. 1979. September 25. URL: http://www.cvce.eu/content/publication/2002/2/22/e7b2919a-a2b3-4354-9dde-bdd8ela5c84d/publishable_en.pdf (дата обращения: 19.06.2016).

67. Обичкина Е.О. Франция в поисках внешнеполитических ориентиров в постбиполярном мире. М.: МГИМО (У) МИД РФ, 2004. 487 с.

68. Council Common Position 2001/931/CFSP of 27 December 2001 On the Application of Specific Measures to Combat Terrorism // OJ.L 344. URL: http://eur-lex.europa.eu/LexUriServ/LexUriServ.do?uri= OJ:L:2001:344:0093:0096:EN:PDF (дата обращения: 19.06.2016).

69. Council Common Position 2003/651 CFSP of 12 September 2003 Updating Common Position 2001/931/CFSP // OJ.L 229. URL: http://eur-lex.europa.eu/LexUriServ/LexUriServ.do?uri=OJ:L:2003:229 :0042:0045:EN:PDF (дата обращения: 19.06.2016).

70. Единый федеральный список организаций, в том числе иностранных и международных организаций, признанных в соответствии с законодательством Российской Федерации террористическими (на 25 октября 2016 г.) / Федеральная служба безопасности Российской Федерации. URL: http://www.fsb.ru/fsb/npd/terror.htm (дата обращения: 14.11.2016).

71. Quartet Statement. London. 2006. January 30. URL: http://www.consilium.europa.eu/ueDocs/cms_ Data/docs/pressdata/en/declarations/88201.pdf (дата обращения: 20.06.2016).

72. Arrêt du Tribunal (deuxième chambre) dans l'affaire T-400/10. 2014. 17 décembre // InfoCuria Case-law of the Court of Justice. URL: http://curia.europa.eu/juris/document/document.jsf?text=\&docid= 160843\&pageIndex=0\&doclang=FR\&mode=req\&dir=\&occ=first\&part=1\&cid=301135 (дата обращения: 20.06.2016). [Judgment of the General Court (Second Chamber) in Case T-400/10. 2014. December 17]

73. EU terrorist list // European Council, Council of the European Union. URL: http://www.consilium. europa.eu/en/policies/fight-against-terrorism/terrorist-list/ (дата обращения: 21.06.2016).

74. Manners I. Normative Power Europe: A Contradiction in Terms? // Journal of Common Market Studies. 2002. Vol. 40, N 2. P. 235-258.

75. Manners I. Assessing the decennial, reassessing the global: Understanding European Union normative power in global politics // Cooperation and Conflict. 2013. Vol. 48, N 2. P. 304-329.

76. Koops J. A. The European Union as an Integrative Power? Assessing the EU's 'Effective Multilateralism' towards NATO and the United Nations. Brussels: VUBPress, 2011. 493 p.

77. Mueller P. Europe's Foreign Policy and the Middle East Peace Process: The Construction of EU Actorness in Conflict Resolution // Perspectives on European Politics and Society. 2013. Vol. 14, N 1. P. 20-35.

78. EU's Position on the Middle East Peace Process: Key Inconsistencies. Paper prepared by a group of humanitarian, development, human rights and peace organizations. 2009. September. URL: http://www. diakonia.se/globalassets/documents/diakonia/policy-and-advocacy/letters-to-decision-makers/090901eu-peace-process-in-the-middle-east.pdf (дата обращения: 21.06.2016). 
Для цитирования: Гудалов Н.Н. Развитие и особенности позиции Европейского союза по основным политическим аспектам разрешения палестино-израильского конфликта // Вестник СПбГУ. Серия 6. Политология. Международные отношения. 2016. Вып. 4. С. 89-107.

DOI: $10.21638 / 11701 /$ spbu06.2016.409

\section{References}

1. Smith M. Institutionalization, Policy Adaptation and European Foreign Policy Cooperation. European Journal of International Relations, 2004, vol. 10, no. 95, pp. 95-136.

2. Ambos A., Von Behr I. The Middle East Peace Process. European Foreign Policy: From Rhetoric to Reality? Eds D. Mahncke, A. Ambos, C. Reynolds. Brussels: Presses Interuniversitaires Européennes, 2004, pp. 293-316.

3. Second Report on European Political Co-operation on Foreign Policy. Copenhagen. 1973. July 23. Annex. URL: http://www.cvce.eu/content/publication/1999/1/1/8b935ae1-0a38-42d4-a97e-088c63d54b6f/publishable_en.pdf (accessed: 04.06.2016).

4. Declaration on European Identity. Copenhagen. 1973. December 14. URL: http://www.cvce.eu/obj/ Declaration_on_European_Identity_Copenhagen_14_December_1973-en-02798dc9-9c69-4b7d-b2c9f03a8db7da32.html (accessed: 04.06.2016).

5. Santa Maria Da Feira European Council, 2000. June 19-20. Presidency Conclusions. Annex V. Common Strategy of the European Union on the Mediterranean Region. URL: http://www.europarl.europa.eu/summits/fei2_en.htm an5 (accessed: 04.06.2016).

6. A Secure Europe in a Better World. European Security Strategy. Brussels, 2003. December 12. URL: http://www.consilium.europa.eu/uedocs/cmsUpload/78367.pdf (accessed: 05.06.2016).

7. Shared Vision, Common Action: A Stronger Europe. A Global Strategy for the European Union's Foreign And Security Policy, 2016. June. URL: https://europa.eu/globalstrategy/sites/globalstrategy/files/eugs_review_web.pdf (accessed: 22.08.2016).

8. Tocci N. Active but Acquiescent: the EU's Response to the Israeli Military Offensive in the Gaza Strip. Brussels: Euro-Mediterranean Human Rights Network Publ., 2009. 89 p.

9. Allen D., Smith M. Europe, the United States and the Middle East: a Case Study in Comparative Policy Making. Journal of Common Market Studies, 1983, vol. 22, no. 2, pp. 125-146.

10. Ginsberg R. H. The European Union in International Politics. Baptism by Fire. Boston, Rowman \& Littlefield, 2001. 307 p.

11. Dannreuther R. Understanding the Middle East Peace Process: A Historical Institutionalist Approach. European Journal of International Relations, 2011, vol. 17, no. 2, pp. 187-208.

12. Müller P. The Europeanization of France's Foreign Policy towards the Middle East Conflict - from Leadership to EU Accommodation. European security, 2013, vol.22, no. 1, pp. 113-128.

13. Pardo S., Peters J. Uneasy Neighbours: Israel and the European Union. Plymouth, Lexington Books, 2010. xii+155 p.

14. Sachar H. M. Israel and Europe. An Appraisal in History. New York, Vintage Books Publ., Toronto, Random House of Canada Limited Publ., 2000. xiii, 398 p.

15. Zaslavskaia N.G. Evoliutsiia institutsional'nogo balansa v ES v kontekste evropeiskoi integratsii [Evolution of the EU institutional balance in the framework of European integration]. Klio, no. 3 (99), pp. 155-160. (In Russian)

16. Morozov V.E. Evropa: orientatsiia vo vremeni i prostranstve [Europe: Self-Alignment in Time and Space]. Rossiia v global'noi politike [перевод], vol. 6, no. 3, pp.78-89. (In Russian)

17. Romanova T. A. Imperiia norm Reguliativnaia ekspansiia ES i ee predely [Norm Empire The EU Regulative Expansion and Its Limits]. Rossiia v global'noi politike, vol. 11, no. 1, pp. 182-192. (In Russian)

18. Mishal'chenko Iu. V., Izotov A. V. Osnovnye faktory formirovaniia otnosheniia Evropeiskogo soiuza $\mathrm{k}$ protsessam evraziiskoi integratsii [The Main Factors Shaping the European Union's Attitude regarding the Processes of Eurasian Integration]. Evraziiskaia integratsiia: ekonomika, pravo, politika, 2014, no. 16, pp. 26-31. (In Russian)

19. Tkachenko S.L. Kontseptsiia energeticheskoi sverkhderzhavy i otnosheniia Rossiiskoi Federatsii i Evrosoiuza v oblasti energetiki [The Concept of Energy Superpower and the Russian Federation - European Union Relations in the Energy Field]. Ekonomika kachestva, 2014, no. 8, pp.84-94. (In Russian)

20. Sovremennye otnosheniia Rossii i Evropeiskogo soiuza: desiat' let posle podpisaniia Soglasheniia o partnerstve i sotrudnichestve [The Contemporary Relations between Russia and the European Union: Ten 
Years after the Signing of the Partnership and Cooperation Agreement]. Materialy Mezhdunarodnoi nauchnoi konferentsii 01.10.2004 [Proceedings of an International Academic Conference, October 1, 2004], School of International Relations of the SPbSU. Ed. by Chief K. Khudoley. St. Petersburg, Saint Petersburg University Press, 2005. 178 p. (European Studies Series; issue 18.) (In Russian)

21. Zykova O. A. Otnosheniia Evropeiskogo Soiuza i Izrailia v kontekste arabo-izrail'skogo konflikta [The European Union - Israel Relations in the Context of the Israeli-Arab Conflict]. Vostokovednyi sbornik [Orientalist Collection], issue 5. Moscow, Institute for Israel and Middle East Studies, 2003, pp.152-165. (In Russian)

22. Kolobov A. O. Pozitsiia Evrosoiuza po otnosheniiu k Izrailiu i Palestinskoi Natsional'noi Avtonomii $\mathrm{v}$ ramkakh blizhnevostochnogo mirnogo protsessa [The European Union's Position with regard to Israel and to the Palestinian National Autonomy in the Framework of the Middle East Peace Process]. Vestnik Nizhegorodskogo universiteta im. N. I. Lobachevskogo, 2009, no. 3, pp. 224-226. (In Russian)

23. Krylov A. V. Protivodeistvie stran Evrosoiuza poselencheskoi politike Izrailia: mify i real'nost' [The European Union Counteraction To Israel's Settlement Policy In The Occupied Arab Territories: Myths And Realities]. Vestnik MGIMO-University, 2014, no. 6 (39), pp. 161-173. (In Russian)

24. Kutrashev D. K. Posrednicheskaia missiia ES v palestino-izrail'skom konflikte [The EU's Mediatory Mission in the Israeli-Palestinian Conflict]. Vsia Evropa [All Europe], 2012, no. 3 (64). (In Russian) Available at: http://www.alleuropa.mgimo.ru/posrednicheskaya-missiya-es-v-palestino-izrailjskom-konflikte (accessed: 06.06.2016).

25. Golubev D.S. Kontseptual'nye osnovy posrednichestva SShA v uregulirovanii arabo-izrail'skogo konflikta na sovremennom etape. Diss. ... kand. polit. nauk [The Conceptual Basis of the USA Mediation in the Settlement of the Israeli-Arab Conflict at the Present Stage. Thesis of PhD]. St. Petersburg, 2010. 286 p. (In Russian)

26. The United Nations Security Council. Resolution 242. 1947. November 22. Available at: https://documents-dds-ny.un.org/doc/RESOLUTION/GEN/NR0/240/94/IMG/NR024094.pdf?OpenElement (accessed: 07.06.2016).

27. Declaration of the Nine Foreign Ministers on the Situation in the Middle East. Brussels. 1973. November 6. Available at: http://www.cvce.eu/content/publication/1999/1/1/a08b36bc-6d29-475c-aadb0f71c59dbc3e/publishable_en.pdf (accessed: 07.06.2016).

28. London European Council. 1977. June 29-30. Presidency Conclusions. Statement on the Middle East. Available at: http://aei.pitt.edu/1410/1/London_june_1977.pdf (accessed: 08.06.2016).

29. The Balfour Declaration. November 2, 1917. The Israel-Arab Reader. A Documentary History of the Middle East Conflict. Eds W. Laqueur, B. Rubin. New York, Penguin Books Publ., 2008, p. 16.

30. The European Council. Venice Declaration. 1980. June 13. Available at: http://eeas.europa.eu/mepp/ docs/venice_declaration_1980_en.pdf (accessed: 08.06.2016).

31. Kimmerling B., Migdal J.S. Introduction to The Palestinian People: A History. Postzionism: A Reader. Ed. by L. J. Silberstein. New Brunswick, Rutgers University Press, 2008, pp. 56-60.

32. Camp David Summit Meetings: Frameworks for Peace. 1978. September 17. The Israel-Arab Reader. A Documentary History of the Middle East Conflict. Eds W.Laqueur, B. Rubin. New York, Penguin Books Publ., 2008, pp. 222-227.

33. Egypt and Israel: Peace Treaty. 1979. March 26. The Israel-Arab Reader. A Documentary History of the Middle East Conflict. Eds W. Laqueur, B. Rubin. New York, Penguin Books Publ., 2008, pp. 227-228.

34. United Nations General Assembly Resolution 35/169. Question of Palestine. 1980. December 15. Available at: http://www.un.org/documents/ga/res/35/a35r169e.pdf (accessed: 09.06.2016).

35. Pyrlin E. D. Sto let protivoborstva: Genezis, evoliutsiia, sovremennoe sostoianie i perspektivy resheniia palestinskoi problemy [One Hundred Years of Confrontation: the Genesis, Evolution, Current Status and Prospects of the Resolution of the Palestinian Issue]. Moscow, Rossiiskaia politicheskaia entsiklopediia (ROSSPEN), 2001. 480 p. (In Russian)

36. Palestine National Council: Declaration of Independence. 1988. November 15. The Israel-Arab Reader. A Documentary History of the Middle East Conflict. Eds W. Laqueur, B. Rubin. New York, Penguin Books Publ., 2008, pp. 354-358.

37. Dehousse R. European Political Cooperation 1 July 1987 - 31 December 1988. European Journal of International Law, 1990, vol. 1, no. 1, pp.378-399.

38. Diplomatic Relations. Permanent Observer Mission of The State of Palestine to the United Nations, 2014. Available at: http://palestineun.org/about-palestine/diplomatic-relations/ (accessed: 10.06.2016).

39. United Nations General Assembly Resolution 67/19. Status of Palestine in the United Nations, 2012. November 29. Available at: http://www.un.org/en/ga/search/view_doc.asp?symbol=A/RES/67/19 (accessed: 17.06.2016). 
40. Madrid European Council. 1989. June 26-27. Presidency Conclusions. Declaration on the Middle East, pp. 12-14. Available at: http://aei.pitt.edu/1453/1/Madrid_june_1989.pdf (accessed: 10.06.2016).

41. Amsterdam European Council. 1997. June 16-17. Presidency Conclusions. Annex III. Available at: http:// www.consilium.europa.eu/uedocs/cms_data/docs/pressdata/en/ec/032a0006.htm (accessed: 10.06.2016).

42. Berlin European Council. 1999. March 24-25. Presidency Conclusions. Available at: http://www. consilium.europa.eu/uedocs/cms_data/docs/pressdata/en/ec/ACFB2.html (accessed: 11.06.2016).

43. Seville European Council, 2002. June 21 and 22. Presidency Conclusions. Declaration on the Middle East, pp.35-36. Available at: http://www.consilium.europa.eu/ueDocs/cms_Data/docs/pressData/en/ ec/72638.pdf (accessed: 12.06.2016).

44. Council Conclusions on the Middle East Peace Process. Brussels, 2009. December 8. Available at: http://eeas.europa.eu/delegations/israel/press_corner/all_news/news/2009/20091208_01_en.htm (accessed: 16.06.2016).

45. Majlis jaamiat ad-duwal al-'arabiyya. Mubaadarat as-salaam al-'arabiyya. Bairut, 2002. 28 mars. Available at: http://www.nad-plo.org/atemplate.php?id=88 (accessed: 06.03.2014).

46. Communiqué issued by the Quartet. New York, 2002. September 17. Available at: http://unispal. un.org/unispal.nsf/fdc5376a7a0587a4852570d000708f4b/54c9e0a5f8ccbd2b85256c3700653ea4?OpenDoc ument (accessed: 16.06.2016)

47. A Performance-Based Roadmap to a Permanent Two-State Solution to the Israeli-Palestinian Conflict. Washington, DC, 2003, April 30. Available at: http://www.mfa.gov.il/MFA/Peace+Process/ Guide+to+the+Peace+Process/A+Performance-Based+Roadmap+to+a+Permanent+Two-Sta.htm (accessed: 16.06.2016).

48. Council Conclusions on the Middle East Peace Process. Brussels, 2012, May 14. Available at: http:// www.eu-un.europa.eu/articles/en/article_12170_en.htm (accessed: 16.06.2016).

49. Solana J. Europe in the World. Boston, 2009, September 17. Available at: http://www.consilium. europa.eu/uedocs/cms_data/docs/pressdata/EN/discours/110218.pdf (accessed: 16.06.2016).

50. Ashton C. Press Briefing, 2011, September 23. Available at: http://ec.europa.eu/avservices/video/ player.cfm? sitelang=en\&ref=79846 (accessed: 17.06 .2016$)$.

51. Quartet Statement. New York, 2011, September 23. Available at: http://www.un.org/news/dh/ infocus/middle_east/quartet-23sep2011.htm (accessed: 17.06.2016).

52. Rettman A. EU Pitches Counter-Offers to Palestinian Statehood Bid. EUobserver, 2011. September 24. Available at: http://euobserver.com/24/113725 (accessed: 17.06.2016).

53. Council Conclusions on the Middle East Peace Process. Brussels, 2012, December 10. Available at: http:// www.consilium.europa.eu/uedocs/cms_Data/docs/pressdata/EN/foraff/134140.pdf (accessed: 18.06.2016).

54. Mogherini F. Statement on the UN Security Council Vote on the MEPP. European Union Delegation to the United Nations, 2014, December 30. Available at: http://eu-un.europa.eu/articles/en/article_15912_ en.htm (accessed: 18.06.2016).

55. Council Conclusions on the Middle East Peace Process. Brussels, 2013, December 16. Available at: http:// www.consilium.europa.eu/uedocs/cms_data/docs/pressdata/EN/foraff/140097.pdf (accessed: 18.06.2016)

56. Ahren R. EU ready to pay Palestinians who renounce right of return. The Times of Israel, 2014, March 24. Available at: http://www.timesofisrael.com/eu-ready-to-pay-palestinians-who-renounce-rightof-return/ (accessed: 18.06.2016).

57. Gudalov N.N. Problemy primeneniia Evropeiskim soiuzom printsipa konditsional'nosti dlia razresheniia palestino-izrail'skogo konflikta (na opyte mirnykh peregovorov 2013-2014 gg.) [Problems in the European Union's Application of the Principle of Conditionality for the Resolution of the IsraeliPalestinian Conflict (Lessons from the 2013-2014 Peace Talks)]. Politika i Obshchestvo [Politics and Society], 2014, no. 5, pp.568-578. Doi: 10.7256/1812-8696.2014.5.12267. (In Russian)

58. Macintyre D. EU on Verge of Abandoning Hope for a Viable Palestinian State. The Independent, 2012, January 12. Available at: http://www.independent.co.uk/news/world/middle-east/eu-on-verge-ofabandoning-hope-for-a-viable-palestinian-state-6288336.html (accessed: 19.06.2016).

59. Guidelines on the eligibility of Israeli entities and their activities in the territories occupied by Israel since June 1967 for grants, prizes and financial instruments funded by the EU from 2014 onwards, 2013, July 19. Available at: http://eeas.europa.eu/delegations/israel/documents/related-links/20130719_guidelines_on_ eligibility_of_israeli_entities_en.pdf (accessed: 19.06.2016).

60. Mezzofiore G. EU Bans Israeli Dairy Products made in Occupied West Bank Settlements form January. International Business Times, 2014, October 10. Available at: http://www.ibtimes.co.uk/eu-bansisraeli-dairy-products-made-occupied-west-bank-settlements-january-1469454 (accessed: 19.06.2016).

61. Copenhagen European Council, 2002. December 12-13. Presidency Conclusions. Available at: http:// www.consilium.europa.eu/ueDocs/cms_Data/docs/pressData/en/ec/73842.pdf (accessed: 19.06.2016). 
62. Council Conclusions on Middle East Peace Process. Brussels, 2009, January 26-27. Available at: http:// www.consilium.europa.eu/uedocs/cms_Data/docs/pressdata/en/gena/105545.pdf (accessed: 19.06.2016).

63. Council Conclusions on Middle East Peace Process. Brussels, 2012, November 19. Available at: http:// www.consilium.europa.eu/uedocs/cms_Data/docs/pressdata/EN/foraff/133604.pdf (accessed: 19.06.2016).

64. Ettaba S.S. Palestinian Statehood Bid Victim of Double Standards. Middle East Online, 2011, September 21. Available at: http://www.middle-east-online.com/english/?id=48143 (accessed: 19.06.2016).

65. Yanover Y. EU: If Netanyahu Builds in Jerusalem, We'll Back PA in Hague. The Jewish Press, 2013, June 6. Available at: http://www.jewishpress.com/news/breaking-news/eu-if-netanyahu-builds-in-jerusalemwell-back-pa-in-hague/2013/06/06/ (accessed: 19.06.2016).

66. O'Kennedy M. Speech in New York, 1979, September 25. Available at: http://www.cvce.eu/ content/publication/2002/2/22/e7b2919a-a2b3-4354-9dde-bdd8e1a5c84d/publishable_en.pdf (accessed: 19.06.2016).

67. Obichkina E. O. Frantsiia v poiskakh vneshnepoliticheskikh orientirov v postbipoliarnom mire [France in Search for Foreign Policy Objectives in a Post-bipolar World]. Moscow, MGIMO-Universitet, 2004. 487 p. (In Russian)

68. Council Common Position 2001/931/CFSP of 27 December 2001 On the Application of Specific Measures to Combat Terrorism. OJ. L 344. Available at: http://eur-lex.europa.eu/LexUriServ/LexUriServ.do ?uri=OJ:L:2001:344:0093:0096:EN:PDF (accessed: 19.06.2016).

69. Council Common Position 2003/651 CFSP of 12 September 2003 Updating Common Position 2001/931/CFSP. OJ. L 229. Available at: http://eur-lex.europa.eu/LexUriServ/LexUriServ.do?uri=OJ:L:2003: 229:0042:0045:EN:PDF (accessed: 19.06.2016).

70. Edinyi federal'nyi spisok organizatsii, $v$ tom chisle inostrannykh i mezhdunarodnykh organizatsii, priznannykh v sootvetstvii s zakonodatel'stvom Rossiiskoi Federatsii terroristicheskimi (na 25 oktiabria 2016 g.), Federalnaia sluzhba bezopasnosti Rossiiskoi Federatsii [The Consolidated Federal List of Organizations, including Foreign and International Organizations, Designated as Terrorist according to the Russian Federation Law (as of 25 October 2016), The Federal Security Service of the Russian Federation]. Available at: http://www. fsb.ru/fsb/npd/terror.htm (accessed 14.11.2016). (In Russian)

71. Quartet Statement. London, 2006, January 30. Available at: http://www.consilium.europa.eu/ueDocs/ cms_Data/docs/pressdata/en/declarations/88201.pdf (accessed: 20.06.2016).

72. Arrêt du Tribunal (deuxième chambre) dans l'affaire T-400/10, 2014. 17 décembre. [Judgment of the General Court (Second Chamber) in Case T-400/10, 2014. December 17]. InfoCuria - Case-law of the Court of Justice. Available at: http://curia.europa.eu/juris/document/document.jsf?text=\&docid=160843\&p ageIndex $=0 \&$ doclang $=F R \&$ mode $=$ req \&dir $=\& o c c=$ first $\& p a r t=1 \& c i d=301135$ (accessed: 20.06.2016).

73. EU terrorist list. European Council, Council of the European Union. Available at: http://www. consilium.europa.eu/en/policies/fight-against-terrorism/terrorist-list/ (accessed: 21.06.2016).

74. Manners I. Normative Power Europe: A Contradiction in Terms? .Journal of Common Market Studies, 2002, vol. 40, no. 2, pp. 235-258.

75. Manners I. Assessing the decennial, reassessing the global: Understanding European Union normative power in global politics. Cooperation and Conflict, 2013, vol. 48, no. 2, pp. 304-329.

76. Koops J. A. The European Union as an Integrative Power? Assessing the EU's 'Effective Multilateralism' towards NATO and the United Nations. Brussels, VUBPress, 2011. $493 \mathrm{p}$.

77. Mueller P. Europe's Foreign Policy and the Middle East Peace Process: The Construction of EU Actorness in Conflict Resolution. Perspectives on European Politics and Society, 2013, vol. 14, no. 1, pp. 20-35.

78. EU's Position on the Middle East Peace Process: Key Inconsistencies. Paper prepared by a group of humanitarian, development, human rights and peace organizations, 2009, September. Available at: http://www. diakonia.se/globalassets/documents/diakonia/policy-and-advocacy/letters-to-decision-makers/090901eu-peace-process-in-the-middle-east.pdf (accessed: 21.06.2016).

For citation: Gudalov N.N. The Development and Characteristics of the European Union's Position on the Principal Political Aspects of the Resolution of the Israeli-Palestinian Conflict. Vestnik SPbSU. Series 6. Political science. International relations, 2016, issue 4, pp. 89-107. DOI: 10.21638/11701/spbu06.2016.409

\footnotetext{
Статья поступила в редакцию 3 сентября 2016 г.;
} рекомендована в печать 19 октября 2016 г. 